ISSN 1392-3196 / e-ISSN 2335-8947

Zemdirbyste-Agriculture, vol. 105, No. 3 (2018), p. 235-242

DOI 10.13080/z-a.2018.105.030

\title{
Intercropping of field pea with annual legumes for increasing grain yield production
}

\author{
Dalibor ŽIVANOV ${ }^{1}$, Aleksandra SAVIĆ ${ }^{1}$, Snežana KATANSKI ${ }^{1}$, \\ Đura KARAGIĆ ${ }^{1}$, Branko MILOŠEVIĆ ${ }^{1}$, Dragan MILIĆ ${ }^{1}$, Vuk ĐORĐEVIĆ ${ }^{1}$, \\ Svetlana VUJIĆ 2 , Đorđe KRSTIĆ 2 , Branko ĆUPINA² \\ ${ }^{1}$ Institute of Field and Vegetable Crops \\ Maksima Gorkog 30, 21000 Novi Sad, Serbia \\ ${ }^{2}$ University of Novi Sad \\ Dositeja Obradovica 8, 21000 Novi Sad, Serbia \\ E-mail: djordjek@polj.uns.ac.rs
}

\begin{abstract}
In temperate regions, normal-leafed field pea still represents an important crop for grain and animal consumption, even though there is increasing interest in afila type cultivars because of their better standing ability. The effect of dual legume intercropping on grain yield of normal-leafed pea was studied during 2015 and 2016 in order to reduce lodging, to improve grain yield stability and to analyse the competitiveness of field pea with annual legumes and wheat. The research involved six species grown as sole crops: normal-leafed pea (Pisum sativum L. (Partim)), semi-leafless pea (Pisum sativum L. (Partim), faba bean (Vicia faba L. (Partim)), white lupin (Lupinus albus L.), fenugreek (Trigonella foenum-graecum L.) and wheat as a control (Triticum aestivum L. emend. Fiori et Paol) and intercrop mixtures of normal-leafed pea with other five species. Grain yield $\left(\mathrm{t} \mathrm{ha}^{-1}\right)$, yield components, land equivalent ratio, relative crowding coefficient and aggressivity value for grain yield were monitored. The highest grain yield of normal-leafed pea $\left(2.87 \mathrm{t} \mathrm{ha}^{-1}\right)$ was obtained from the mixture with semi-leafless pea in 2015 and from the mixture of wheat + normal-leafed pea $\left(5.26 \mathrm{t} \mathrm{ha}^{-1}\right)$ in 2016 . The lowest number of pods and seeds per plant was formed by normal-leafed pea as a sole crop in 2015 (5.2 and 19.2, respectively). The obtained results showed that a thousand seed weight differed between treatments; however, the differences were not significant. The highest land equivalent ratio (1.40), relative crowding coefficient (4.44) and the positive value of aggressivity (0.19) were observed in the mixture of fenugreek + normal-leafed pea. The results demonstrated that semi-leafless + normalleafed pea and fenugreek + normal-leafed pea are the most beneficial mixtures for grain production, while faba bean was a less suitable component for intercropping with normal-leafed pea.
\end{abstract}

Key words: grain yield, intercropping, land equivalent ratio, legumes, wheat.

\section{Introduction}

Intercropping system represents the simultaneous cultivation of at least two crops in the same field during a growing season (Willey, 1985), in order to increase fodder and grain production. In Europe and before "fossilization" of agriculture with synthetic fertilizers and pesticides, intercropping of annual legumes and cereals was one of the most common agricultural practices (HauggaardNielsen et al., 2011). Intercropping of grain legumes with cereals or other crops has been a promising practice in order to improve use efficacy of resources like land, water, soil, nutrients and solar radiation, while at the same time reducing risk in terms of unstable yield and thus increasing the productivity and profitability of the farming system (Bedoussac et al., 2015; Gaba et al., 2015). Karkanis et al. (2016) reported lower yields in organic production system than in traditional one. Therefore, intercropping mixtures can be used as a model to increase legume grain production. Intercropping is a powerful way to promote a more diversified plant community in the field, thereby enabling complementary and facilitative relationships. In these systems legumes are a key functional group, and are highly valued for the agroecological services they provide, mainly because they improve soil fertility through biological nitrogen fixation (Muhammed, Serkan, 2014; Duchene et al., 2017). According to Lithourgidis et al. (2011), intercropping provides insurance against crop failure, or unstable market prices for a given commodity, especially in areas subject to extreme weather conditions, such as frost, drought and flood. Thus, it offers greater financial stability than sole cropping, which makes the system particularly suitable for labour-intensive small farms.

Please use the following format when citing the article:

Živanov D., Savić A., Katanski S., Karagić Đ., Milošević B., Milić D., Đorđević V., Vujić S., Krstić Đ., Ćupina B. 2018. Intercropping of field pea with annual legumes for increasing grain yield production. Zemdirbyste-Agriculture, 105 (3): $235-242$ DOI $10.13080 / \mathrm{z}-\mathrm{a} .2018 .105 .030$ 
Field pea (Pisum sativum L.) is a common legume in crop rotations and quite productive in temperate conditions. In the organic systems in the European Union pea is a significant species since it is a source of biologically fixed nitrogen and it provides high-quality forage, rich in crude protein and mineral elements (Corre-Hellou, Crozat, 2005; Lauk, Lauk, 2008). However, grain production can be very unstable due to stem lodging, which can cause significant losses, especially for normal-leafed cultivars. Therefore, intercropping can be a suitable tool for growing species prone to lodging combining them with a species with upper growing stem. Legume + cereal intercropping is one of the patterns used to overpass the problems with pea stability on the one hand, and, on the other hand, to act as a nitrogen input for cereals in organic or low input production systems. Legume can be grown also with another legume by using the same principle, where one crop is supporting the other. Legume + legume intercropping of varieties or species with complementary characteristics is also a promising way of optimising the management of natural resources. However, there is little published data in regard to this kind of intercropping even though some reports present beneficial effects on at least one component in the mixture (Voisin et al., 2013; Mikić et al., 2015). According to Ćupina et al. (2011), the following four principles are essential for successful intercropping of two annual legumes species: the same time of sowing, the similar growing habit, the similar time of maturing for harvest, one component has good standing ability (supporting crop), and the other is susceptible to lodging (supported crop). Mikić et al. (2015) reported that faba bean or white lupin as annual legumes with good standing ability are usually sown in wide rows, which favours weed invasion. On the other hand, those authors emphasized that annual legumes like pea and vetches, which are prone to lodging suppress weeds more efficiently but with certain losses of lower leaves, biomass quality and grain yield. By intercropping these two groups of legumes, one with good and the other with the poor standing ability, it may be beneficial for both, especially in terms of weed reduction and utilisation of sunlight. Thus, in intercropped mixtures of faba bean or semi-leafless pea, of good standing ability, with normal-leafed pea, faba bean and semileafless pea would provide support for normal-leafed pea, while contributing from better sunlight utilisation and reduced weed growth delivered by normal-leafed pea. Nevertheless, legume + legume or legume + cereal intercropping can be affected by several factors, such as cultivar selection, seeding ratios and competition between mixture components, weather conditions, etc. (Carr et al., 2004). Competition is one of the factors that can have a significant impact on yield of mixture compared with pure stands (Caballero et al., 1995). A number of indices, such as a land equivalent ratio, relative crowding coefficient, and agrressivity have been proposed to describe competition within and economic advantages of intercropping systems (Banik et al., 2006; Dhima et al., 2007). Among the indices used for assessing competition between intercrops, land equivalent ratio is most commonly used for intercrop versus sole crop comparisons (Agegnehu et al., 2006). This indicates that the legumes grown in such mixtures will achieve higher productivity per unit area than the legumes grown in pure stand under the given climatic conditions.
The objectives of this study were (i) to determine the effect of dual intercropping - normal-leafed field pea with annual legumes and wheat on grain yield of field pea, and (ii) to examine the competitive relationship of field pea with annual legumes and wheat in intercrop system.

\section{Materials and methods}

Location and weather conditions. A field experiment was carried out in two successive years, 2015 and 2016, at the same experimental field of the Institute of Field and Vegetable Crops Novi Sad, Serbia on slightly carbonated loamic chernozem - Calcic Gleyic Chernozem (CH-cc.gl-lo), according to WRB (2014); pH 7.2 in $\mathrm{KCl}$, organic matter $2.2 \%, 6.3 \% \mathrm{CaCO}_{3}, 0.2 \%$

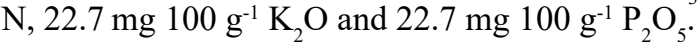

The climate of Serbia is moderately continental. Mean monthly air temperature is $12.3^{\circ} \mathrm{C}$ and an annual sum of precipitation is around $600 \mathrm{~mm}$. The average air temperature of two experimental years was within the long-term average (1981-2016). However, in May and July 2015 and in April and June 2016 temperatures were higher than the average values. From February to July, the amount of precipitation in 2015 was $12.8 \mathrm{~mm}$ below and in $201690.2 \mathrm{~mm}$ above the long-term average (Fig. 1).

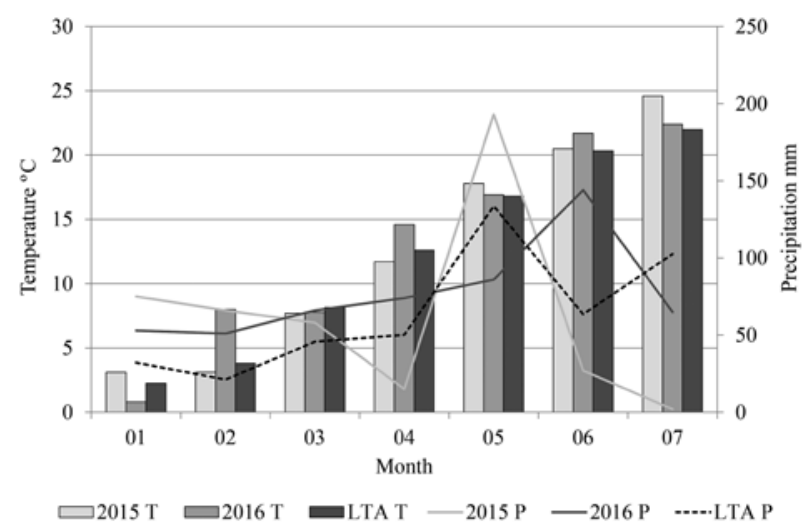

Figure 1. Long-term average (LTA, 1981-2016) and total monthly precipitation (P) and average monthly air temperature (T) for 2015 and 2016 growing seasons

Plant material and experimental set-up. The field experiment included six different species planted separately as sole crop and as intercrop mixture. The normal-leafed spring field pea (Pisum sativum L. (Partim), 'Dukat') was used as a supported crop in mixed intercrops with different supporting crops: faba bean (Vicia faba L. (Partim), 'Miroč'), white lupin (Lupinus albus L., 'Vesna'), fenugreek (Trigonella foenum-graecum L., Fg 1025), wheat (Triticum aestivum L. emend. Fiori et Paol, 'Nataša') and semi-leafless pea (Pisum sativum L. (Partim), 'Partner'). The main characteristics of used cultivars are shown in Table 1 . The seed rates used in sole crops were: normal-leaf pea (100 plants $\left.\mathrm{m}^{-2}\right)$, faba bean (80 plants $\left.\mathrm{m}^{-2}\right)$, white lupin $\left(60\right.$ plants $\left.\mathrm{m}^{-2}\right)$, fenugreek (200 plants $\left.\mathrm{m}^{-2}\right)$, wheat (480 plants $\mathrm{m}^{-2}$ ) and semi-leafless pea $\left(100\right.$ plants $\left.\mathrm{m}^{-2}\right)$. Seed rates in intercrops were $50 \%$ of seed rates used for each species sown as a sole crop. This seeding rate was applied to enable adequate space for developing of both intercrops while at the same time to be dense enough to suppress weeds and to be economically justified. The used seed rates are common 
Table 1. The characteristics of annual grain legumes and wheat cultivars

\begin{tabular}{|c|c|c|c|c|c|}
\hline \multirow[b]{2}{*}{ Species } & \multirow[b]{2}{*}{ Cultivar } & \multicolumn{4}{|c|}{ Parameters } \\
\hline & & $\begin{array}{l}\text { time of } \\
\text { flowering }\end{array}$ & $\begin{array}{c}\text { stem } \\
\text { length }\end{array}$ & $\begin{array}{c}\text { lodging* } \\
\text { during vegetation }\end{array}$ & $\begin{array}{c}\text { thousand seed } \\
\text { weight }\end{array}$ \\
\hline Normal-leafed pea & Dukat & medium & medium & 2 & medium \\
\hline Semi-leafless pea & Partner & early & long & 4 & medium \\
\hline Faba bean & Miroč & medium & medium & 4 & high \\
\hline White lupin & Vesna & early & medium & 4 & high \\
\hline Fenugreek & Fg 1025 & medium & medium & 4 & - \\
\hline Wheat & Nataša & early & medium & 4 & medium \\
\hline
\end{tabular}

* -5 = no lodging, $1=$ entire plot lodging

in this part of Europe and mainly depend on the cultivar and local practice. The traditional way of intercropping of pea and wheat was used as a control. In both study years, wheat was a previous crop.

The plot size was $5 \mathrm{~m}^{2}(5 \times 1 \mathrm{~m})$. A field trial was set up as a randomized block design with three replications including thirteen treatments. The seedbed preparation included ploughing, disk harrowing and cultivation. Crops were sown in the first half of February in 2015 and 2016. Considering the size, form and thousand seed weight, the sowing was performed in two separate passes. Each species was sown in separate rows within one treatment, using a Wintersteiger handpushed single row seeder, in alternate rows with row spacing of $20 \mathrm{~cm}$. The crops were grown without using any fertilizers or pesticides. Ten normal-leafed pea plants per plot in each replication were randomly chosen for assessment of yield components: number of pods and seeds per plant as well as a thousand seed weight. All plots were harvested mechanically using a Wintersteiger classic plot combine, at the end of June in both years. After the harvest, the seeds from intercrop plots were separated on the seed selector, in order to measure grain yield of each species. Grain yield was adjusted to the standard moisture for each crop.

The land equivalent ratio was used as a tool for measuring the yield advantage obtained by intercropping of crops or varieties compared to sole crop stands (Mikić et al., 2015). The land equivalent ratio (LER) for seed yield was calculated using the following formula (Willey, 1985):

LER = yield (supporting crop A) / yield (sole crop A) + yield (supporting crop B) / yield (sole crop B), where LER $>1.0$ indicates an advantage for mixture than for sole cropping, LER $=1.0$ represents the equal advantages between mixture and sole cropping, LER $<1.0$ indicates less advantage for mixture than for a sole crop.

The relative crowding coefficient and aggressivity value were used to calculate the competitive relationship between the two crops in a mixture (De Wit, 1960). The term relative crowding coefficient of plant species gives a measure of whether that species has produced more or less yield than expected. Aggressivity value gives a simple measure of how much the relative yield increase in species "a", and is greater than that for species " $b$ ". For relative crowding coefficient (RCC) and aggressivity value $(\mathrm{AV})$ the following formulas were used:

$$
\mathrm{RCCa}=(\mathrm{Yab} \times \mathrm{Zba}) /(\mathrm{Yaa}-\mathrm{Yab})-\mathrm{Zab},
$$$$
\mathrm{RCC}=(\mathrm{RCCa} \times \mathrm{RCCb}) \text {, }
$$$$
\mathrm{AV}=(\mathrm{Yab} / \mathrm{Yaa} \times \mathrm{Zab})-(\mathrm{Yba} / \mathrm{Ybb} \times \mathrm{Zba})
$$

where RCCa represents the relative crowding coefficient for the component crop " $a$ " in the mixture, Yab is the intercrop yield of the crop "a", Yaa - a pure stand yield of crop "a", Zba - a sown proportion of crop "a" in a mixture of " $b$ "; if RCC is $>1$ there is a yield advantage in mixture, $\mathrm{RCC}=1$ represents no yield advantage, $\mathrm{RCC}<1$ means that there is a yield disadvantage.

Index A shows dominance of the crop "a" over the crop " $b$ " and vice versa when they are sown together. If index $\mathrm{A}=0$, it means that both crops are equally competitive. If crop "a" has a positive value and crop "b" has a negative value, it indicates crop "a" dominance over the crop "b" and vice versa.

Statistical analysis. The average grain yield and yield components in sole crop and intercrop mixtures were analysed by the analysis of variance $(A N O V A)$ and Tukey's test was used to determine significant differences for all means at $p \leq 0.05$ in Statistica, version 13.2.

\section{Results}

Grain yield and grain yield components. The grain yield values for sole crops and mixtures over the two growing seasons are shown in Table 2. Most of the treatments had a higher yield in 2016, with exception of treatments with white lupin, semi-leafless pea and the mixture of fenugreek + normal-leafed pea, which achieved higher yield in 2015. The normal-leafed pea grown as a sole crop produced a grain yield of $2.67 \mathrm{tha}^{-1}$ in the first year and $4.29 \mathrm{t} \mathrm{ha}^{-1}$ in the second year. Out of five mixtures, in 2015 there were no statistical differences between intercropping treatments, and the lowest yield was obtained in the treatment white lupin + normalleafed pea $\left(1.83 \mathrm{t} \mathrm{ha}^{-1}\right)$ and the highest in the mixture of semi-leafless + normal-leafed pea $\left(2.87 \mathrm{t} \mathrm{ha}^{-1}\right)$. In the second year, grain yield in mixtures ranged from $2.61 \mathrm{tha}^{-1}$ (fenugreek + normal-leafed pea) to $5.26 \mathrm{t} \mathrm{ha}^{-1}$ (wheat + normal-leafed pea).

Table 2. Grain yield ( $\mathrm{t} \mathrm{ha}^{-1}$ ) of sole crops and intercropping mixtures for 2015 and 2016

\begin{tabular}{lcc}
\hline \multirow{2}{*}{ Treatment } & \multicolumn{2}{c}{ Year } \\
\cline { 2 - 3 } & 2015 & 2016 \\
\hline Normal-leafed pea (NLP) & $2.67 \mathrm{a}$ & $4.29 \mathrm{bc}$ \\
Semi-leafless pea (SLP) & $3.01 \mathrm{a}$ & $2.68 \mathrm{de}$ \\
Faba bean (FB) & $1.74 \mathrm{a}$ & $5.18 \mathrm{ab}$ \\
White lupin (WL) & $2.24 \mathrm{a}$ & $1.61 \mathrm{e}$ \\
Fenugreek (FG) & $0.31 \mathrm{~b}$ & $0.38 \mathrm{f}$ \\
Wheat (W) & $2.04 \mathrm{ab}$ & $6.32 \mathrm{a}$ \\
FB + NLP & $2.01 \mathrm{ab}$ & $4.51 \mathrm{bc}$ \\
SLP + NLP & $2.87 \mathrm{a}$ & $3.58 \mathrm{~cd}$ \\
FG + NLP & $2.85 \mathrm{a}$ & $2.61 \mathrm{de}$ \\
W + NLP & $2.14 \mathrm{a}$ & $5.26 \mathrm{ab}$ \\
WL + NLP & $1.83 \mathrm{ab}$ & $2.67 \mathrm{de}$ \\
& $2.15 \mathrm{~B}$ & $3.55 \mathrm{~A}$ \\
\hline
\end{tabular}

Note. Small letters represent the differences between the treatments within one year; capital letters represent the differences between the average values of the treatments. 
Based on a two-year average, the highest ratio of normal-leafed pea in the mixtures was in the combination with fenugreek $(92.1 \%)$, and the lowest was obtained in the intercropping with wheat (35.8\%) (Fig. 2). The average values showed that in the intercrops faba bean + normal-leafed pea and wheat + normal-leafed pea supporting crops had a higher ratio than pea, $54.3 \%$ for faba bean and $64.2 \%$ for wheat. In 2015 , normal-leafed pea had a higher contribution in the majority of mixtures compared to 2016. The exception was in the mixture with fenugreek where in 2015 the contribution of normalleafed pea was $91.9 \%$ and in $201692.3 \%$. Considering companion crops, the lowest ratio in the mixture was obtained by fenugreek in $2015(7.7 \%)$ and the highest by wheat in $2016(73.6 \%)$.

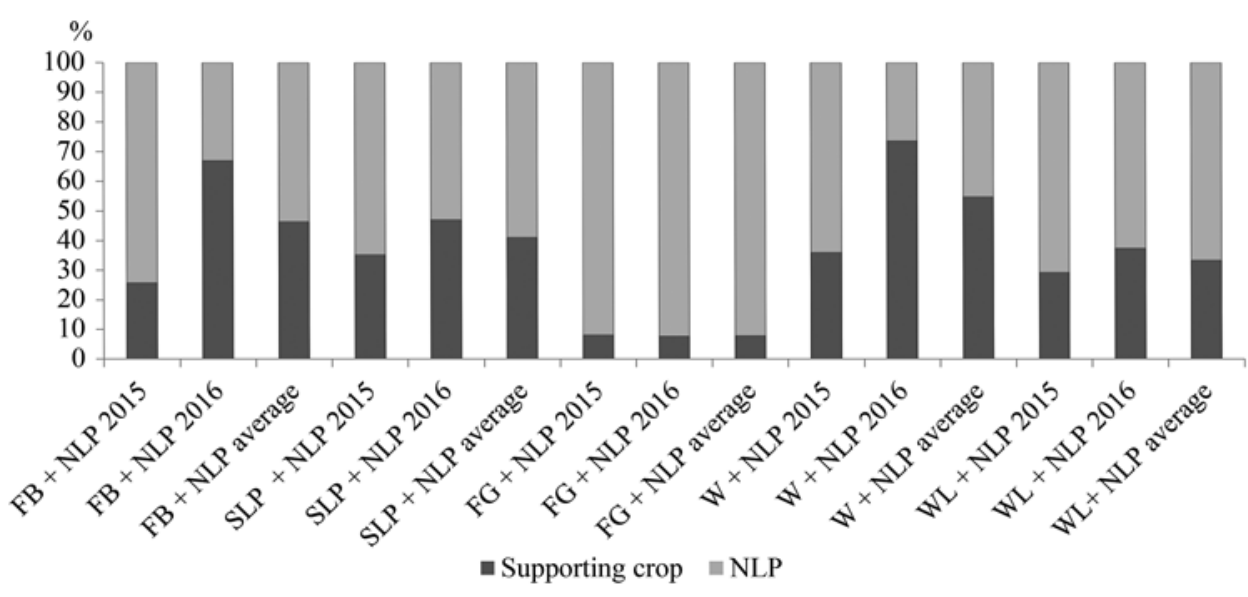

FB - faba bean, NLP - normal-leafed pea, SLP - semi-leafless pea, FG - fenugreek, W - wheat, WL - white lupin

Figure 2. The ratio of companion crops in the grain yield of intercropping mixtures in 2015 and 2016

In all treatments, the number of pods per plant of normal-leafed pea was higher in 2016 reaching maximum in the mixture with semi-leafless pea (10.8) (Table 3). The lowest number was recorded in 2015 in sole crop of normal-leafed pea (5.2), which was not statistically different compared to the values of the mixtures with white lupin (5.9) and wheat (6.4). In the first year, normal- leafed pea had a higher number of seeds per pod, while in all other treatments higher yield was in the second year. In 2015, the number of seeds ranged from 19.2 (normalleafed pea sole crop) to 26.9 (normal-leafed pea + faba bean) and in 2016 from 19.9 (normal-leafed + faba bean) to 34.1 (normal-leafed pea + fenugreek).

Table 3. Effect of intercropping on normal-leafed pea (NLP) productivity in sole crop and in mixtures during 20152016

\begin{tabular}{|c|c|c|c|c|c|c|}
\hline \multirow{2}{*}{ Treatment } & \multicolumn{2}{|c|}{ Number of pods plant ${ }^{-1}$} & \multicolumn{2}{|c|}{ Number of seed plant ${ }^{-1}$} & \multicolumn{2}{|c|}{ Thousand seed weight $g$} \\
\hline & 2015 & 2016 & 2015 & 2016 & 2015 & 2016 \\
\hline NLP & $5.2 \mathrm{~d}$ & $10.4 \mathrm{a}$ & $19.2 \mathrm{c}$ & $33.1 \mathrm{a}$ & $240.2 \mathrm{a}$ & $191.6 \mathrm{a}$ \\
\hline $\mathrm{NLP}+\mathrm{FB}$ & $7.6 \mathrm{ab}$ & $7.9 \mathrm{bc}$ & $26.9 \mathrm{ab}$ & $19.9 \mathrm{~b}$ & $221.5 \mathrm{abc}$ & $184.9 \mathrm{a}$ \\
\hline $\mathrm{NLP}+\mathrm{SLP}$ & $7.1 \mathrm{abc}$ & $10.8 \mathrm{a}$ & $25.5 \mathrm{ab}$ & $32.8 \mathrm{a}$ & $208.2 \mathrm{bc}$ & $183.8 \mathrm{a}$ \\
\hline $\mathrm{NLP}+\mathrm{FG}$ & $8.2 \mathrm{a}$ & $10.5 \mathrm{a}$ & $29.8 \mathrm{a}$ & $34.1 \mathrm{a}$ & $232.4 \mathrm{ab}$ & $193.5 \mathrm{a}$ \\
\hline $\mathrm{NLP}+\mathrm{W}$ & $6.4 \mathrm{bcd}$ & $6.5 \mathrm{c}$ & $22.2 \mathrm{bc}$ & $20.7 \mathrm{~b}$ & $208.8 \mathrm{bc}$ & $255.1 \mathrm{a}$ \\
\hline $\mathrm{NLP}+\mathrm{WL}$ & $5.9 \mathrm{~cd}$ & $9.1 \mathrm{ab}$ & $20.8 \mathrm{bc}$ & $29.4 \mathrm{a}$ & $232.8 \mathrm{ab}$ & $193.2 \mathrm{a}$ \\
\hline & $6.7 \mathrm{~B}$ & $9.2 \mathrm{~A}$ & $24.1 \mathrm{~B}$ & $28.3 \mathrm{~A}$ & $222.6 \mathrm{~A}$ & $200.3 \mathrm{~B}$ \\
\hline
\end{tabular}

Note. Small letters represent the differences between the treatments within one year; capital letters represent the differences between the average values of the treatments and between the years; FB - faba bean, SLP - semi-leafless pea, FG - fenugreek, W - wheat, $\mathrm{WL}$ - white lupin.

Most of the treatments had higher values of thousand seed weight in 2015, except for mixture with wheat, which achieved higher values in 2016. In both years, normal-leafed pea had the lowest thousand seed weight in the mixture with semi-leafless pea $-208.2 \mathrm{~g}$ in 2015 and $183.8 \mathrm{~g}$ in 2016 , respectively. In the first year, the highest thousand seed weight was recorded in the sole crop of the normal-leafed pea $(240.2 \mathrm{~g})$ and in the second year in the normal-leafed pea sown with wheat $(255.1 \mathrm{~g})$. However, in 2016, there were no significant differences at all between the treatments.

Competition among component crops. The data of the competitive ability parameters, namely the land equivalent ratio, relative crowding coefficient and aggressivity value are given in Table 4.
Among all intercrop combinations, mixtures of fenugreek + normal leafed pea in 2015 and wheat + normal-leafed pea in 2016 achieved the highest land equivalent ratio -1.65 and 1.80 , respectively. Positive land equivalent ratio values were also obtained by intercropping semi-leafless pea + normal-leafed pea in both years (1.03 and 1.06), and in the mixture of fenugreek + normal leafed pea (1.15) in 2016. In the mixtures of semi-leafless + normal-leafed pea and fenugreek + normal-leafed pea, relative crowding coefficient value was more than $1-1.05$ and 4.44 , respectively. The lowest relative crowding coefficient $(0.47)$ was obtained from white lupin + normal-leafed pea intercropping.

Normal-leafed pea was the dominant species $(A>0)$ in the mixtures with semi-leafless pea, fenugreek 
Table 4. Land equivalent ratio (LER), relative crowding coefficient (RCC) and aggressivity value (AV) of legumes and wheat grown in intercrops in 2015-2016

\begin{tabular}{|c|c|c|c|c|c|c|c|}
\hline \multirow{2}{*}{$\begin{array}{l}\text { Mixture } \\
(50: 50 \%)\end{array}$} & \multicolumn{2}{|c|}{ LER } & \multicolumn{3}{|c|}{$\mathrm{RCC}$} & \multicolumn{2}{|c|}{ AV } \\
\hline & 2015 & 2016 & $\begin{array}{l}\text { other } \\
\text { crops }\end{array}$ & NLP & $\mathrm{RCC}$ & $\begin{array}{l}\text { other } \\
\text { crops }\end{array}$ & NLP \\
\hline $\mathrm{FB}+\mathrm{NLP}$ & 0.86 & 0.93 & 1.05 & 0.75 & 0.78 & 0.17 & -0.17 \\
\hline SLP + NLP & 1.03 & 1.06 & 0.88 & 1.19 & 1.05 & -0.15 & 0.15 \\
\hline $\mathrm{FG}+\mathrm{NLP}$ & 1.65 & 1.15 & 1.69 & 2.63 & 4.44 & -0.19 & 0.19 \\
\hline $\mathrm{W}+\mathrm{NLP}$ & 0.88 & 1.80 & 1.31 & 0.62 & 0.81 & 0.37 & -0.37 \\
\hline $\mathrm{WL}+\mathrm{NLP}$ & 0.75 & 0.85 & 0.60 & 0.78 & 0.47 & -0.13 & 0.13 \\
\hline
\end{tabular}

NLP - normal-leafed pea, FB - faba bean, SLP - semi-leafless pea, FG - fenugreek, $\mathrm{W}$ - wheat, $\mathrm{WL}$ - white lupin

and with white lupin. Normal-leafed pea had positive aggressivity values in the mixture with semi-leafless pea (0.15), fenugreek (0.19) and with white lupin (0.13). In the other mixtures, faba bean and wheat were the dominant species as measured by the positive value of aggressivity.

\section{Discussion}

The intercropping of legumes and cereal for forage and grain production has been widely studied by numerous authors (Agegnehu et al., 2006; Lithourgidis et al., 2006; Dhima et al., 2007; Borghi et al., 2013). Jensen (1996) has emphasized that cereals in intercropping with legumes produce higher yields compared to those produced without inputs, mainly nitrogen fertilizers. This was confirmed in the present study, supported with the fact that the mixture of normal-leafed pea and wheat produced the highest grain yield. However, in such mixtures cereals can be suppressive and have the impact on legume development. This was shown by the analysed parameters (relative crowding coefficient and aggressivity value), which demonstrated that in those mixtures cereals represented the dominant species. These results were in agreement with those previously reported by Neugschwandtner and Kaul (2015). They reported that oats strongly outcompeted pea when they were grown together. On the other hand, a two-legume mixture had a better impact on both, yield and the pea growth. Intercropping one legume species with another is less studied than all other models of intercropping, especially the intercrops of annual legumes with cereals or perennial legumes with grasses (Mikić et al., 2012). However, our results showed the importance and possibilities of growing two legumes in the same field.

Soil and weather conditions were favourable for germination and grain yield production of field pea (normal-leafed and semi-leafless) and other crops, such as faba bean, fenugreek and wheat. However, the soil $\mathrm{pH}$ value was less favourable for the growth of white lupin, which performed better on acidic and sandy-surfaced soils than on neutral-to-alkaline and fine-textured soils (Hartung et al., 2002; David et al., 2014). Field pea and other crops can be grown on a wide range of soil types (Wielbo et al., 2015), with the optimal $\mathrm{pH}$ value from 6.8 to 7.4 (Mengel, Kirkby, 2012).

High amount of precipitation in 2016, especially at the flowering and pod-filling stage had a positive effect on grain yield of field pea and other crops. The same results were reported by Payne et al. (2000) when both winter and growing season precipitation was high. The obtained results showed that the grain yield of faba bean and wheat, grown in a sole crop or in the intercrop, significantly varied between two experimental years. Šarūnaitė et al. (2010) and Kadžiulienè et al. (2011) concluded that grain yield of intercropped species significantly varied between the experimental years.

Grain yield of normal-leafed pea varied greatly in sole crop compared to intercrops between two seasons. Similar results were observed by Dore et al. (1998) who tested variability of field pea yield over multiyear trials. Nemecek et al. (2008) emphasized that pea grown as a sole crop is more exposed to the influence of abiotic factors than in the intercrop systems. The present study indicates that the obtained grain yield of normal-leafed pea in mixtures with fenugreek, faba bean and semileafless pea was higher than in the other mixtures (Fig. 2). In those mixtures, normal-leafed pea had the highest number of pods and seeds per plant in 2015 . On the other hand, in 2016 with more favourable weather conditions, those parameters were not significantly different between normal-leafed pea as sole crop and in the examined mixtures (Table 3 ). This can come from the fact that the number of pods and seeds per plant in many legumes has the strongest relationship with seed yield (French, 1990). According to Mikić et al. (2012), good performance achieved in the mixtures could be the result of improved standing ability of normal-leafed pea grown with wheat, faba bean and semi-leafless pea, where normal-leafed pea has available space within the stand and contributes to better utilisation of sunlight, and at the same time reduces weed growth. Also, pod and seed number was more important in explaining yield differences than a thousand seed weight, which did not vary significantly between the treatments. However, differences between the years were significant. Those differences were noticed specifically in the mixtures of normal-leafed pea + fenugreek and normal-leafed pea + white lupin. In the first mixture, the values of grain yield and yield components could be explained by the fact that in both years undersown crop, such as fenugreek, had a slower growth and did not compete with the pea for water and nutrients. In that mixture normal-leafed pea developed a higher number of pods per plant and a higher thousand seed weight. On the other hand, growth of white lupin was slower due to soil $\mathrm{pH}$ value, which enabled better pea development. It is assumed that pea plants used white lupin as a support more efficiently.

In 2016, crops produced higher yield in both sole and intercropping treatments. However, in 2015 the obtained results showed advantages of sole crops compared to intercropping. It is assumed that there was mutual inhibition between the legumes in intercrop, considering resources and space, which affected the growth and development of the species and lead to shading one species by another and greater usage of 
energy. Thus, intercropping benefits highly depend on cultivar selection, seeding ratios and planting patterns, which could also affect the species growth in intercrop (Vandermeer, 1984).

Yield components contributed to a better understanding of the intercropping influence on the achieved yield among intercropped species in comparison with the sole crop. However, the beneficial effect of intercropping could be seen through land equivalent ratio, relative crowding coefficient and aggressivity value. The obtained land equivalent ratio values above 1.0 for mixtures of fenugreek + normal-leafed pea, semi-leafless pea + normal-leafed pea, wheat + normalleafed pea, indicated that the legumes grown in mixtures were advantageous compared to the legumes grown as sole crops. In this study, relative crowding coefficient values of normal-leafed pea in a mixture with fenugreek and semi-leafless pea were greater than one, and the aggressivity values were positive, which indicated that normal-leafed pea produced higher grain yield and it was the dominant component in the mixture with fenugreek and semi-leafless pea. In these mixtures there was an advantage of intercropping for exploiting the resources of the environment. On the other hand, the aggressivity values were greater for faba bean and wheat than for normal-leafed pea, indicating that faba bean and wheat were more competitive partners than normal-leafed pea. The reason for this lies in the ability of wheat to uptake a greater proportion of soil nitrogen (Corre-Hellou, Crozat, 2005; Marioitti et al., 2009), whereas legumes, in this case pea, increased nitrogen concentration in the soil by symbiotic nitrogen fixation, which favoured wheat growth and development (Voisin et al., 2002).

Growing normal-leafed pea together with fenugreek and semi-leafless pea can positively affect yield stability. According to Fernández-Aparicio et al. (2011), fenugreek has the ability to suppress weeds, which probably contributed to the efficiency of the intercrop. Semi-leafless pea is not prone to lodging and improves standing ability in the intercrop with normalleafed pea, whereas normal-leafed pea contributes to the intercrop by better weed control (Mikić et al., 2012). This positive mutual interaction of two types of field pea makes them valuable companions in the intercropping system, which was proven by the achieved yield and land equivalent ratio value.

The land equivalent ratio value below 1 was obtained in both years in the mixture of white lupin + normal-leafed pea and faba bean + normal-leafed pea, and in 2015 in the wheat + normal leafed pea combination. Even though normal-leafed pea achieved similar yields in intercrop with white lupin and as a sole crop, this mixture did not prove advantageous in the complementary use of available natural resources. Another intercrop mixture that did not prove to be beneficial, considering the low land equivalent ratio value in both years, was the mixture of faba bean with normal-leafed pea. According to all the obtained results, the most beneficial mixtures for grain production are semi-leafless + normal-leafed pea, and fenugreek + normal-leafed pea, due to yield stability, positive land equivalent ratio index, relative crowding coefficient and aggressivity values.

\section{Conclusions}

This study provides further evidence that legume with legume intercropping is a promising alternative to intensive agricultural systems. The productivity of legume sole crops and intercrops depended on the legume species and varied depending on year's cultivation conditions.

1. In the first experimental year, the highest grain yield of normal-leafed pea was produced in the mixture with fenugreek and semi-leafless pea, while in the second year the higher grain yield was achieved with faba bean and wheat.

2. Based on a two-year average, the highest ratio of normal-leafed pea in the mixtures was in the combination with fenugreek and the lowest ratio was obtained in the intercropping with wheat.

3. The highest number of pods and seeds per normal-leafed pea plant significantly differed among the treatments in both years The obtained results showed that a thousand seed weight was higher in all treatments in the year 2015 with less favourable weather conditions.

4. Among all intercrop combinations, the highest land equivalent ratio was observed in 2015 and 2016 in the mixtures with semi-leafless pea and fenugreek, and also in the mixtures with wheat in 2015. Therefore, the highest relative crowding coefficient value was achieved with semi-leafless pea and fenugreek. Normal-leafed pea was the dominant species in the mixtures with semileafless pea, fenugreek and with white lupin, while faba bean and wheat outcompeted field pea in the mixture.

\section{Acknowledgements}

This research was supported by The LEGATO Project "LEGumes for the Agriculture of Tomorrow", project No. 613551, and is funded by the European Union under the FP7 Programme.

Received 24102017 Accepted 29052018

\section{References}

1. Agegnehu G., Ghizam A., Sinebo W. 2006. Yield performance and land-use efficiency of barley and fababean mixed cropping in Ethiopian highlands. European Journal of Agronomy, 25: 202-207. https://doi.org/10.1016/j.eja.2006.05.002

2. Banik P., Midya A., Sarkarand B. K., Ghose S. S. 2006. Wheat chickpea intercropping systems in an additive series experiment: advantages and weed smothering. European Journal of Agronomy, 24: 325-332. https://doi.org/10.1016/j.eja.2005.10.010

3. Bedoussac L., Journet E. P., Hauggaard-Nielsen H., Naudin C., Corre-Hellou G., Jensen E. S., Prieur L., Justes E. 2015. Ecological Principles underlying the increase of productivity achieved by cereal-grain legume intercrops in organic farming. A review. Agronomy for Sustainable Development, 35 (3): 911-935.

https://doi.org/10.1016/j.eja.2005.10.010

4. Borghi E., Crusciol C. A. C., Mateus G. P., Nascente A. S., Martins P. O. 2013. Intercropping time of corn and palisadegrass or guineagrass affecting grain yield and forage production. Crop Science, 53: 629-636. https://doi.org/10.2135/cropsci2012.08.0469 
5. Caballero R., Goicoechea E. L., Hernaiz P. J. 1995. Forage yield and quality of common vetch and oat sown at varying seeding ratios and seeding rates of common vetch. Field Crops Research, 41: 135-140. https://doi.org/10.1016/0378-4290(94)00114-R

6. Carr P. M., Horsley R. D., Poland W. W. 2004. Barley, oat and cereal-pea mixtures as dryland forages in the Northern Great Plains. Agronomy Journal, 96: 677-684. https://doi.org/10.2134/agronj2004.0677

7. Corre-Hellou G., Crozat Y. 2005. $\mathrm{N}_{2}$ fixation and N supply in organic pea (Pisum sativum L.) cropping system as affected by weeds and pea weevil (Sitona lineatus L.). European Journal of Agronomy, 22: 449-458. https://doi.org/10.1016/j.eja.2004.05.005

8. Ćupina B., Mikić A., Stoddard F. L., Krstić Đ., Justes E., Bedoussac L., Fustec J., Pejić B. 2011. Mutual legume intercropping for forage production in temperate regions. Lichtfouse E. (eds). Sustainable Agriculture Reviews 7: Genetics, Biofuels and Local Farming Systems. Springer, Dordrecht, p. 347-365. https://doi.org/10.1007/978-94-007-1521-9 12

9. David G., Borcean A., Imbrea F., Botos L. 2014. White lupin (Lupinus albus L.): a plant fit to improve acid soils in south-western Romania and an important source of protein. Research Journal of Agricultural Science, 46 (1): 198-202.

10. De Wit C. T. 1960. On competition. Verslag LandbouwKundige Onderzoek, 66: 1-28.

11. Dhima K. V., Lithourgidis A. S., Vasilakoglou I. B., Dordas C. A. 2007. Competition indices of common vetch and cereal intercrops in two seeding ratio. Field Crops Research, 100: 249-256. https://doi.org/10.1016/j.fcr.2006.07.008

12. Dore T., Meynard J., Sebillotte M. 1998. The role of grain number, nitrogen nutrition and stem number in limiting pea crop (Pisum sativum) yields under agricultural conditions. European Journal of Agronomy, 8 (1-2): 29-37. https://doi.org/10.1016/S1161-0301(97)00006-3

13. Duchene O., Vian J. F., Celette F. 2017. Intercropping with legume for agroecological cropping systems: complementarity and facilitation processes and the importance of soil microorganisms. A review. Agriculture, Ecosystems and Environment, 240: 148-161. https://doi.org/10.1016/j.agee.2017.02.019

14. Fernández-Aparicio M., Emeran A. A.-M., Rubiales D. 2011. Inter-cropping faba bean with berseem, fenugreek or oat can contribute to broomrape management. Grain Legumes, 56: 31.

15. French R. J. 1990. The contribution of pod numbers to field pea (Pisum sativum L.) yields in a short growing-season environment. Australian Journal of Agricultural Research, 41 (5): 853-862. https://doi.org/10.1071/AR9900853

16. Gaba S., Lescourret F., Boudsocq S., Enjalbert J., Hinsinger P., Journet E. P., Navas M. L., Wery J., Louarn G., Malezieux E., Pelzer E., Prudent M., Ozier-Lafontaine H. 2015. Multiple cropping systems as drivers for providing multiple ecosystem services: from concepts to design. Agronomy for Sustainable Development, 35 (2): 607-623. https://doi.org/10.1007/s13593-014-0272-z

17. Hartung W., Leport L., Ratcliffe R. G., Sauter A., Duda R., Turner N. C. 2002. Abscisic acid concentration, root $\mathrm{pH}$ and anatomy do not explain growth differences of chickpea (Cicer arietinum L.) and lupin (Lupinus angustifolius L.) on acid and alkaline soils. Plant and Soil, 240: 191-199. https://doi.org/10.1023/A:1015831610452

18. Hauggaard-Nielsen H., Peoples M. B., Jensen E. S. 2011. Faba bean in cropping systems. Grain Legumes, 56: 32-33.

19. Jensen E. S. 1996. Grain yield, symbiotic $\mathrm{N}_{2}$ fixation and interspecific competition for inorganic $\mathrm{N}$ in pea-barley intercrops. Plant and Soil, 182: 25-38. https://doi.org/10.1007/BF00010992
20. Kadžiulienė Ž., Šarūnaitė L., Deveikytė I. 2011. Effect of pea and spring cereals intercropping on grain yield and crude protein content. Ratarstvo i povrtarstvo, 48 (1): 183-188. https://doi.org/10.5937/ratpov1101183K

21. Karkanis A., Ntatsi G., Kontopoulou C. K., Pristeri A., Bilalis D., Savvas D. 2016. Field pea in European cropping systems: adaptability, biological nitrogen fixation and cultivation practices. Notulae Botanicae Horti Agrobotanici Cluj-Napoca, 44: 325-336. https://doi.org/10.15835/nbha44210618

22. Lauk R., Lauk E. 2008. Pea-oat intercrops are superior to pea-wheat and pea-barley intercrops. Acta Agriculturae Scandinavica, Section B: Soil and Plant Science, 58: 139-144. https://doi.org/10.1080/09064710701412692

23. Lithourgidis A. S., Vasilakoglou I. B., Dhima K. V., Dordas C. A., Yiakoulaki M. D. 2006. Forage yield and quality of common vetch mixtures with oat and triticale in two seeding ratios. Field Crops Research, 99: 106-113. https://doi.org/10.1016/j.fcr.2006.03.008

24. Lithourgidis A. S., Dordas A. C., Damalas C. A., Vlachostergios D. N. 2011. Annual intercrops: an alternative pathway for sustainable agriculture. Australian Journal of Crop Science, 5: 396-410.

25. Marioitti M., Masoni A., Ercoli L., Arduini I. 2009. Aboveand below-ground competition between barley, wheat, lupin and vetch in a cereal and legume intercropping system. Grass Forage Science, 64: 401-412. https://doi.org/10.1111/j.1365-2494.2009.00705.x

26. Mengel K., Kirkby E. A. 2012. The soil as a plant nutrient medium. Mengel K. et al. (eds). Principles of plant nutrition. Springer, p. 15-110. https://doi.org/10.1007/978-94-010-1009-2 2

27. Mikić A., Ćupina B., Mihajlović V., Krsitć Dj., Djordjević V., Perić V., Srebrić M., Antanasović S., Marjanović-Jeromela A., Kobiljski B. 2012. Forage legume intercropping in temperate regions: models and ideotypes. Lichtfouse E. (ed.). Sustainable agriculture reviews. Springer, p. 161-182. https://doi.org/10.1007/978-94-007-5449-2_7

28. Mikić A., Ćupina B., Rubiales D., Mihailović V., Šarūnaitè L., Fustec J., Antanasović S., Krstić Đ., Bedoussac L., Zorić L., Đorđević V., Perić V., Srebrić M. 2015. Models, developments, and perspectives of mutual legume intercropping. Advances in Agronomy, $130(6): 337-419$ https://doi.org/10.1016/bs.agron.2014.10.004

29. Muhammed D., Serkan A. 2014. Intercropping of legumes with cereal crops in particular with the perennials to enhance forage yields and quality. Battelo C. et al. (eds). Perennial crops for food security. FAO Publishing, chapter 16, p. 221-228.

30. Nemecek T., Richthofen J. S., Dubois G., Casta P., Charles R., Pahl H. 2008. Environmental impacts of introducing grain legumes into European crop rotations. European Journal of Agronomy, 28: 380-393.

https://doi.org/10.1016/j.eja.2007.11.004

31. Neugschwandtner R. W., Kaul H. P. 2015. Nitrogen uptake, use and utilization efficiency by oat-pea intercrops. Field Crops Research, 179: 113-119. https://doi.org/10.1016/j.fcr.2015.04.018

32. Payne W. A., Rasmussen P. E., Chen C., Goller R., Ramig R. E. 2000. Precipitation, temperature and tillage effects upon productivity of a winter wheat-dry pea rotation. Agronomy Journal, 92: 933-937. https://doi.org/10.2134/agronj2000.925933x

33. Šarūnaitė L., Deveikytė I., Kadžiulienė Ž. 2010. Intercropping spring wheat with grain legume for increased production in an organic crop rotation. ZemdirbysteAgriculture, 97 (3): 51-58. 
34. Vandermeer J. 1984. The interpretation and design of intercrop systems involving environmental modification by one of the components: a theoretical framework. Biological Agriculture and Horticulture, 2: 135-156. https://doi.org/10.1080/01448765.1984.9754424

35. Voisin A., Salon C., Munier-Jolain N., Ney B. 2002. Quantitative effects on soil nitrate, growth potential and phenology on symbiotic nitrogen fixation of pea (Pisum sativum L.). Plant and Soil, 243: 31-42. https://doi.org/10.1023/A:1019966207970

36. Voisin A. S., Guéguen J., Huyghe C., Jeuffroy M. H., Magrini M. B., Meynard J. M., Mougel C., Pellerin S., Pelzer E. 2013. Legumes for feed, food, biomaterials and bioenergy in Europe: a review. Agronomy for Sustainable Development, 34 (2): 361-380. https://doi.org/10.1007/s13593-013-0189-y
37. Wielbo J., Podleśna A., Kidaj D., Podleśny J., Skorupska A. 2015. The diversity of pea micro symbionts in various types of soils and their effects on plant host productivity. Microbes and Environments, 30: 254-261. https://doi.org/10.1264/jsme2.ME14141

38. Willey R.W. 1985. Evaluation and presentation of intercropping advantages. Experimental Agriculture, 21: 119-133. https://doi.org/10.1017/S0014479700012400

39. WRB. 2014. World reference base for soil resources. World Soil Resources Reports No. 106. FAO, Rome.

ISSN 1392-3196 / e-ISSN 2335-8947

Zemdirbyste-Agriculture, vol. 105, No. 3 (2018), p. 235-242

DOI $10.13080 /$ z-a.2018.105.030

\title{
Sẻjamụjų žirnių auginimas su kitais vienamečiais pupiniais augalais, siekiant padidinti grūdų derlių
}

\author{
D. Živanov ${ }^{1}$, A. Savić ${ }^{1}$, S. Katanski ${ }^{1}$, Đ. Karagić ${ }^{1}$, B. Milošević ${ }^{1}$, D. Milić ${ }^{1}$, V. Đorđević ${ }^{1}$, \\ S. Vujić ${ }^{2}$ Đ. Krstić ${ }^{2}$ B. Ćupina
}

${ }^{1}$ Lauko augalų ir daržovių institutas, Serbija

${ }^{2}$ Novi Sad universitetas, Serbija

\begin{abstract}
Santrauka
Vidutinio klimato regionuose lapuotieji žirniai vis dar yra svarbus augalas, auginamas grūdams ir gyvulių mitybai. Tačiau dèl didesnio atsparumo išgulimui didèja susidomèjimas pusiau belapių žirnių (afila tipo) veislèmis. Siekiant sumažinti išgulimą, pagerinti grūdų derliaus stabilumą ir nustatyti sejjamųjų žirnių konkurencinę gebą su vienamečiais pupiniais augalais bei kviečiais, 2015 ir $2016 \mathrm{~m}$. tirta dvinarių pupinių augalų pasèlių įtaka lapuotujų žirnių grūdų derliui. Tirtos šešios rūšys; auginti vieni: lapuotasis sejjamasis žirnis (Pisum sativum L. (Partim)), pusiau belapis sejjamasis žirnis (Pisum sativum L. (Partim), sejjamoji pupa (Vicia faba L. (Partim)), baltasis lubinas (Lupinus albus L.), vaistinè ožragè (Trigonella foenum-graecum L.) ir paprastasis kvietys (Triticum aestivum L. emend. Fiori et Paol.) kaip kontrolinis augalas, ir penkių rūšių lapuotụjų žirnių dvinariai pasėliai. Buvo vertintas grūdu derlius $\left(\mathrm{t} \mathrm{ha}^{-1}\right)$, derliaus komponentai, žemès ekvivalento santykis, santykinis išstūmimo koeficientas ir agresyvumo vertès. Didžiausias derlius buvo gautas $2015 \mathrm{~m}$. lapuotụjų žirnių grūdų $\left(2,87 \mathrm{t} \mathrm{ha}^{-1}\right)$, juos auginant mišinyje su pusiau belapiais žirniais, ir $2016 \mathrm{~m}$. - kviečių + lapuotujų žirnių mišinio $\left(5,26 \mathrm{t} \mathrm{ha}^{-1}\right)$. Mažiausias ankštaru ir vieno augalo sẻklų skaičius (atitinkamai 5,2 ir 19,2) buvo nustatytas 2015 m. lapuotuosius žirnius auginant vienus.

Eksperimento rezultatai parodè, kad 1000-čio grūdu svoris skyrèsi tarp tirtu variantu, tačiau skirtumai nebuvo esminiai. Didžiausias žemès ekvivalento santykis $(1,40)$, santykinis išstūmimo koeficientas $(4,44)$ ir teigiama agresyvumo verte $(0,19)$ buvo nustatyti ožragès + lapuotụjų žirnių mišinio. Tyrimo duomenimis, auginti grūdams naudingiausi yra pusiau belapių žirnių + lapuotujjų žirnių ir ožragių + lapuotujų žirnių mišiniai, o sejjamosios pupos buvo mažiau tinkantis komponentas auginti dvinariuose pasėliuose su lapuotaisiais žirniais.
\end{abstract}

Reikšminiai žodžiai: dvinariai pasėliai, grūdų derlius, kviečiai, žemės ekvivalento santykis. 